\title{
Cold War and Social Protection in Burma and Malaysia
}

\author{
Michele Mioni and Klaus Petersen
}

\section{Introduction}

It is often said that the Cold War was a battle of hearts and minds-a conflict between two rival models for society battling to become the legitimate and preferred horizon of the future for people. Whereas the Iron Curtain during the early Cold War remained a stable line of division through Europe, for emerging countries outside Europe the battle was more intense and open. This was not least the case in formerly colonized countries. Following the Communist victory in China in 1949, US policy-makers certainly considered South East Asia (SEA) a Cold War

M. Mioni $(\bowtie)$

SOCIUM Research Center on Inequality and Social Policy, University of Bremen, Bremen, Germany

e-mail: michele.mioni@uni-bremen.de

K. Petersen

Centre for Welfare State Research \& Department of History, University of Southern Denmark, Odense, Denmark e-mail: klaus.petersen@sdu.dk 
hotspot and a pivotal case for containing the spread of Communism (Westad 2017).

Cold War studies have focused mainly on military aspects, foreign policies and various forms of cultural diplomacy. Less attention has been directed toward the links between the Cold War and welfare state development. Obinger and Schmitt (2011) showed that systemic competition is one important explanatory factor for the growth in social spending in the Organisation for Economic Co-operation and Development (OECD)-world since 1945. However, we still know very little about the mechanisms behind this (for a discussion, see Petersen 2013). In this chapter, we scrutinize the ways in which Western actors integrated social reforms as part of an anti-Communist strategy in SEA and how this was reflected in the domestic context. We will notably consider the actions of Britain, the US and the International Labour Office.

One of the classical explanations of the origins of the welfare state considers social reforms as a bulwark against social unrest and revolutionary movements. Social policy mitigated the socio-political effects of economic and industrial changes and ensured political consensus and legitimation (Spitzer 1962). This anti-revolutionary strategy triggered reforms even in the colonies (Seekings 2011; see Schmitt, Chap. 6, this volume), playing an important role also in the Cold War. Social reforms were an effective way to hamper Communism and other revolutionary movements, legitimizing the existing power relations and building state structures. IR-scholar Klaus Knorr picked up this point already in 1950; speaking mainly to an US audience, Knorr presented the European welfare state and ended up arguing for it as a domestic defense strategy:

it is plausible that the democratic welfare state is the most constructive defense of the free world against Communist expansion, for it offers to many societies, rightly or wrongly dissatisfied with the free-enterprise economy they had, an alternative to the attractions of Communism. (Knorr 1950, 448)

As we will argue, the early social security and welfare reforms in SEA were no stranger to these considerations. This line of argumentation does not exclude competing explanations on welfare state growth, such as 
modernization and democratization. On the contrary, in the 1950 s modernization discourses provided the theoretical and political tools for Western interventions and state-building (Gilman 2003). Modernization, social security and political stabilization complemented the struggle against Communism in the area. Cold War was a crosscutting moment of competition, which affected or triggered social reforms. The Cold War led to reconsidering social reforms as part of modernization strategies, state-building and the anti-Communist struggle. Domestic policymakers either agreed upon or made use of reform agendas, to carry on their own political agendas which often had a nationalistic and Socialist bend that did not necessarily fit with the goals and economic paradigms of the Western powers.

Recent trends in Cold War historiography have focused on the interplay of the two superpowers with other international and regional actors (Westad 2005, 2017; Bradley 2010). Similarly, we consider the interaction of Western interests and the emerging non-Communist ruling classes in the two former Southeast Asian colonies of Burma and Malaysia. Both countries shared a common British colonial heritage and there, according to some observers of the time, "labor movements were comparatively well delineated before the war and [where] subsequent conditions have combined to further their growth. [...] At the present time Malaya and Burma have the only labor movements in the area worthy of the name" (Thompson 1947, 14). While the decolonization was the historical context of these reforms, the local and international policy-makers operated within two different institutional frameworks, as Burma was independent since 1947, while Malaya gained independence only ten years later. The common ground of social security reforms was rather geopolitical concerns connected to the Cold War.

The chapter looks at how the new international paradigms of "social security" were introduced in SEA and inspired both Western experts and local policy-makers to projects of state-building. During and immediately after the war, indeed, the Western powers, the newly born United Nations and the ILO contributed to put "social security" at the very foundations of reconstruction policies (ILO 1944). Welfare state development in Burma and Malaysia was structured by a number of factors, of which anti-Communism was only one (others being ethnic cleavages, 
religion, political parties, economic growth or state capacity). Yet, the idea of social welfare reforms became integrated into the Cold War struggle for hearts and minds. ${ }^{1}$ Our study connects to the ongoing debate about colonial legacies in social policy development (see Cooper 1996; Eckert 2006). However, whereas this strand of literature emphasizes the variations among former Western colonies, we argue that the Cold War was a crosscutting factor that put social reforms on the agenda and influenced the timing of reform.

However, this is not meant to say that the Western powers spoke with one voice or acted in unison in this respect. Especially in the US the "welfare state" did not have a good press, labeled as "Socialism", and in 1951 President Truman declared it a "scare word" (Petersen 2013, 231). Even among the advocates of a socio-economic soft-power strategy we find a conflict between those, like the US State Department, favoring economic growth and modernization, and others (like the ILO) with a broader reform agenda, including social security. The social reforms in Malaysia were still promoted by the British under the paradigms and rules of colonial development. On the contrary, the US — and to a certain extent the ILO_-already framed their aid and assistance to Burma in a post-colonial understanding of socio-economic development. SEA was therefore also the ground for a competition between the various Western actors; the ILO's assistance programs were in line with US President Truman's doctrine on foreign aid, whereas Britain did not look favorably at the interferences of the international organizations in its dependent territories. These perspectives were not necessarily mutually exclusive; often the rhetoric of development complemented the promotion of social security schemes and other social services.

The chapter starts with a comparative overview of the geopolitical conditions under which Burma and Malaysia gained independence and with the importance of the perceived Communist threat in shaping their institutional and political settings. In the following section, we discuss how

\footnotetext{
${ }^{1}$ In this chapter, we decided to consider exclusively the former British colonies, except for the Indian case, which should be dealt separately. In order to stress the Anglo-American strategy with regard to the nexus Cold War/welfare state during decolonization, we also left out the case of French colonies. Anyway we intend to deal more systematically with this subject with further studies on the field.
} 
Western anti-Communist strategies in SEA entailed different approaches, including economic aid, industrialization and social reform. These eventually came to define a Western way of promoting a model of development to counter the spread of Communism in the area. In the third section, we briefly look at the major social reforms introduced in both countries, to assess the way in which they might be framed as antiCommunist policies. Finally, we draw some conclusions on how welfare social policies became part of a strategy allowing for a progressive nonCommunist strategy that signaled an anti-colonialist third-way position between Communism and US capitalism. We base our analysis on a mixed bag of sources: archival documents and published sources, such as academic articles and studies by contemporary observers and scholars. We will use this literature as a primary source to account for the Western takes on the "e base question" in SEA, which was interwoven with the rise of Communism in the context of decolonization. ${ }^{2}$

\section{Burma and Malaysia: From British Colonies to Independent States}

World War II (WWII) signaled a watershed for the process of decolonization. The war fueled nationalism in the colonies and weakened the colonial powers. In the Atlantic Charter (1941, \$3), Churchill and Roosevelt promised "to respect the right of all people to choose the form of government under which they will live", and these ideas were echoed by De Gaulle at the Brazzaville Conference of 1944. In the following years, the United Nations became a platform for decolonization debates; the UN Charter (Chapter IX, articles 73-74) defended the right to selfdetermination, and served as a platform for national liberation movements, denouncing colonial powers (see Jensen 2016). The process of decolonization varied from country to country. In most cases, the Cold

\footnotetext{
${ }^{2}$ For interpretive and practical reasons, we focus on Anglo-American views and strategies concerning the use of social security in Burma and Malaysia, rather than on the systematic tracing of the policy process behind reforms within the two countries.
} 
War framed and influenced the path to independence, and the two countries under scrutiny make no exception.

Burma had been a British colony since 1886; the British made Burma an Indian province that experienced a period of economic growth and modernization. However, as this was mainly to the benefit of British companies and migrant communities from India or Britain, it triggered a nationalist movement in Burma, resulting in growing social and political unrest. In 1937, Burma again separated from India and was granted a constitution with a fully elected assembly. However, this did neither end the nationalist striving for independence nor the conflicts with the British. One of the driving forces of the protest was the strong Burmese Communist movement whose ranks were swollen during the Japanese occupation. Granting independence to Burma in 1947 was mainly the result of British problems with controlling the situation in the colony, and, as the country did not join the Commonwealth, direct British influence in Burma was limited.

The 1947 constitution included a Western-style liberal democratic parliament and political system, with a welfare-statist outlook including ideas of economic planning, state ownership of public utilities, while still guaranteeing private business (Trager 1958, 4-5). In the British House of Lords the new constitution was labeled as a blueprint for the development of a welfare state:

The new Constitution of Burma [...] proclaims a more varied list of individual rights, both male and female, than the Declaration of the Rights of Man or the Constitution of the United States of America and its acceptance of the duties of the State to secure the fulfilment of these rights is in complete accordance with the modern view of the functions of a welfare state. ${ }^{3}$

However, the realization of these promises of a welfare state future was not easily achieved, due to internal political conflicts, lack of resources and a weak state (Taylor 1987, Chap. 4). Burma witnessed political

\footnotetext{
${ }^{3}$ HMSO, Burma Independence Bill, 25 November 1947, vol. 152 cc. 846-924, London, 1947. http://hansard.millbanksystems.com/lords/1947/nov/25/burma-independence-bill\# S5LV0152P0_19471125_HOL_58.
} 
turmoil and domestic rebellions by Communist and ethnic groups that threatened the basic functions of the state-and at the same time called for a positive political reform agenda to strengthen the legitimacy of the politically dominant Anti-Fascist People's Freedom League (AFPFL) —a Socialist coalition of anti-colonial movements. Aung San, the leader of the Burmese independence movement, was a former Communist who had turned increasingly nationalistic and cooperated with the Japanese during the war. In the spring of 1945 he founded the AFPFL together with the Burmese Communist Party.

Burmese non-alignment was driven more by domestic factors than idealism. Anti-colonialism was widespread in Burma, something also clearly stated by numerous reports by British and US intelligence agencies, and neutralism allowed the government to demonstrate its independence of Western powers (Than 2013). This emphasis on Burmese independence appealed to Socialists within the government, workers and the rural population, and defended the government against Communist accusations of being Anglo-American puppets. The Burmese governments were thus in a difficult situation, as foreign aid was very much needed but almost impossible to accept. A Commonwealth loan of 1950 was never used, and in 1954 Burma declined assistance through the Colombo-Plan (Adeleke 2004).

Things turned out differently in Malaysia. From the late nineteenth century on the country had gradually become part of the British Empire. Growing exports of rubber and tin supported the economy but also fueled nationalist protests, as the economic development benefitted mainly British and immigrant groups. During WWII Malaya was occupied by Japan. The defeat of the British Empire contributed to the growing anti-colonial sentiments, and the occupation had strong negative effects on rubber and tin production, leaving the Malaysian economy in a bad shape.

Malaysian independence was more troublesome, and divorce from the colonizers took a long time. After the defeat of Japan in 1945, colonial rule was restored. British initiatives for democratic reform triggered widespread protest from the Malay population, as the reform granted citizenship and equal rights also to Chinese and Indian residents. Consequently, in 1948, the idea of universal citizenship was given up, and political 
turmoil turned into open insurrection; from 1948 to 1960 the British and the Commonwealth armies were engaged in guerrilla warfare against the Communist insurgency triggered by the Malayan National Liberation Army (MNLA), the military arm of the Malaysian Communist Party (MCP).

The timing of the social legislation reforms in Malaysia followed this change of the British strategy against the MNLA, opening up to political and social enhancement to win both the "hearts" (the emotional support of the people) and the "minds" (the consensus of the people motivated by "rational self-interest"). Even though the threat of Communism (and Communist China) remained a factor in the country, the British succeeded with establishing an inter-ethnic and mildly reformist "Alliance", built around the dominating party, United Malays National Organization (UMNO), with the non-Communist Malayan Chinese Association (MCA) and the Malayan Indian Congress (MIC) participating. They won the national elections of 1955 and formed the first government after independence in 1957. Immediately after independence, though, revolts by MNLA insurgents went on until 1989, but mostly these were local outbreaks, increasingly characterized by ethnical claims (Boon Kheng 2009).

Burma and Malaysia differed in size and economic capacity but also shared many characteristics. Being former British colonies close to China and following a non-alignment policy in international affairs (more pronounced in Burma than in Malaysia), the countries were dominated by agriculture and had limited state capacity. Politically, both countries became dominated by party-alliances growing out of the struggle for independence and uniting both nationalist and Socialist groups. Both countries engaged in strategies for economic modernization and the development of industrial production.

In the 1940 s and 1950 s they also developed ambitious social reform agendas. Even if not fully realized, they included the gradual expansion of social protection schemes inspired by social security as well as land reforms, educational reforms and developing industrial relations. In the long run, the goal was to start a genuine process of modernization; in the short run, these plans and the promises they made served to limit the Communist appeal to the national publics. As argued by Dean (1950, 
200), the military security outlook of the US and British policy-makers aligned well with these domestic goals: "For if the Asian nations, still as a low level of development, are now to devote their meager resources to the building up of a war machine, will this not mean the indefinite postponement of the economic and social improvements which, in their opinion, would prove the only effective bulwark against Communism?" (see also Chancellor 1951 for a similar argument).

In both countries, the Communists had played important roles in the struggle for independence, and the parties participated in democratic elections and had regional influence. Likewise, the local ruling parties had a clearly — but not always outspoken — anti-Communist profile. This was also recognized by American and British observers. The foreign policy doctrine of non-alignment (especially in Burma) left the door open for cooperation with both China and the USSR, while both AFPFL in Burma and the "Alliance" in Malaysia had moderate Socialist platforms at home. Yet, Communism was generally considered a threat in terms of the stability and legitimacy of the state by both parties. It was considered a possible competitor for the support of the industrial working class, smallscale farmers and intellectuals.

In Burma, the first years of independence were characterized by strong political and military conflicts between rivaling Communist and ethnic groups (Taylor 1987). Following the Communist victory in China in 1949, the northern areas of Burma were controlled by Kuomintang troops and consequently attracted the attention of both China and the US. Until the early 1950s, rebelling Communist groups controlled northern parts of the country, resulting in direct military conflicts with government troops. However, the Communists also appeared as a legal party, as competitors to AFPFL on the domestic parliamentary scene. The Burmese governments thus had the triple task of controlling the state, modernizing the country, ensuring the unity of the Burmese territory. Political turmoil in Burma led to the establishment of a military regime in 1962, led by Ne Win and his Burma Socialist Program Party, advocating the "Burmese way to Socialism". With the introduction of a one-party regime Burma was lost for democracy for the coming decades.

The "Malaysian Emergency" was instead a major anti-colonial guerilla warfare, where Communist stances mixed with ethnic rivalries; the 
MNLA was mainly mobilizing the ethnic and unassimilated Chinese minority (almost $38 \%$ of the population) but also some ethnic Malayans. However, the insurgency did not ground on merely ethnic bases, as the MNLA proselytized among the rural lower classes and the dispossessed. The rebellion spread outside the great cities and had in the countryside and jungle the material bases where to develop. The MNLA mainly attacked infrastructure, rubber plantations and tin industries, which constituted the framework of Malaysian economy, also directly affecting British economic interests. Albeit the insurgency never stepped up into a mass uprising, it turned out as an escalade of insurgent incidents that reached their peak in 1951-1952, when the rebellion lost momentum (Komer 1972).

The British stick-and-carrot response aimed at separating the rebels from their social basis. The British operated coercive measures such as resettlement and food control, while launching programs for improving social services and living standards in the most underdeveloped areas, which were implemented from 1950 onward. These included the support of inter-ethnic national trade unions, educational reform and a thorough plan of social security, comprehensive of social insurances, healthcare, regulation of working hours and public housing (Mackenzie 1952). Alongside social reform the government passed, under the supervision of the British colonial offices, several projects of economic development and planning, such as the Rural Industrial Development Authority and the Draft Development Plan, which introduced elements of Keynesian planning and favored the growth of public social services through a policy of investments (Rudner 1972).

\section{The Western Actors and the Anti-Communist Strategies in South East Asia: Economic Development and Social Security}

SEA quickly became a hotspot of the Cold War. Communist China, the US-led rebuilding of Japan and the Korean War (1950-1953) signaled the importance of the region for the superpowers. US analysts particularly 
saw in the Communist seizure of power the beginning of a Communist offensive in the region to be countered through "the necessary combination of political and military means" (Sacks 1950, 247). The American government kept the position acquired in the Pacific during WWII in order to control the spread of Communism. According to the "domino theory", the collapse of non-Communist regimes in Burma and Malaysia and their turning toward the Socialist bloc would cause a serious threat to US security interests: "If Burma or Indochina can be held against communism, we can probably hold all of Southeast Asia. If either Burma or Indochina falls, Siam would probably follow, and Southeast Asia would be practically defenseless against the onrush of communism." 4 Consequently, the Western powers closely monitored domestic developments in SEA countries. The major powers shared an interest in stabilizing the new democracies and in fighting the threat of Communism, leading to a high level of coordination and sharing of information. ${ }^{5}$

The American experts were aware of the relevancy of the "social question" to understand the spread of Communism in the area and the multifaceted quests for social enhancement and higher standards of living among the local population (Thompson and Adloff 1950). For this reason, the Western policy advisors stressed the importance to carry on a state-building process through circumscribed social services (mostly healthcare and limited measures of social protection) and an assisted program of development and industrialization. This was supposed to ensure the creation of the financial bases for the development of sounder welfare states along the Western lines (Mills 1949; Buss 1949).

British ILO civil servant Wilfrid Benson recommended the stabilization of the whole area through an incremental social policy including social services and healthcare, labor legislations, the creation and support of reformist workers' organizations. By the help of Western aid, these policies were supposed to accompany economic development and industrialization

\footnotetext{
${ }^{4}$ FRUS, 1950, Vol. 6, document 115, 'Policy Statement prepared in the Department of State, 16 June 1950'.

${ }^{5}$ TNA, Cabinet Papers, CAB 129/29, 'Survey of Communism in Countries outside the Soviet Orbit, 13 September 1948'.
} 
(see Becker, Chap. 7, this volume). They were of capital importance for geopolitical considerations, as "the countries of SEA will be unable to play their part in the peace of prosperity of the world without drastic improvements in the economic and social life of their peoples. [...] The change is that the countries will need economic and social assistance which can aid their political evolution" (Benson 1947, VIII). He also suggested to gradually implement public policies that met the workers' specific social needs and universal social welfare:

an improved standard of living is one of the essentials for stability in Southeast Asia. [...] The change would help to close the gap between the employed and the rest of the population, and, with that pride which newly won selfgovernment can often inspire, the assumption by national governments of the direction of social services may lead to an unexpected response in the desire of the peoples for higher standards of living. (Benson 1947, X-XI)

However, the implementation of this strategy had to be deployed on a case-by-case basis. In Burma, numerous reports underlined the strong skepticism against foreign aid and support from the Western powers, even though material welfare and social development were needed. As stated in a report from the US consul in Rangoon in September 1946 on the Burmese government, "they cannot produce rabbits from an empty hat". ${ }^{6}$ In November 1947, the US chargé in Rangoon pointed out that, taking the strong anti-US opinion in Burma into account, the best counteroffensive might be "concrete US assistance maternal and infant welfare as the most efficient means of winning the masses". ${ }^{7}$ In the following months a bilateral agreement between Burma and the US on educational exchange was established, while also technical equipment (for civil purposes) was made available. ${ }^{8}$ In a policy statement by the Department of State of June 1950 it was explained that "if this present cabinet can, with the help of American technical experts, initiate and successfully carry out

\footnotetext{
${ }^{6}$ FRUS, 1946, Vol. 8, document 5, 'Telegram from the Consul General at Rangoon (Packer) to Department of State, 28 September 1946'. See also document 8, 'Telegram from the Acting Secretary of State to the Chargé in United Kingdom (Gallman), 8 November 1946'.

${ }^{7}$ FRUS, 1947, Vol. 6, document 54, 'Telegram from the Acting Secretary of State to the Consul General at Rangoon, 21 August 1947’.

${ }^{8}$ FRUS, 1947, Vol. 6, document 55, 'Telegram from the Acting Secretary of State to the Embassy in Burma, 19 December 1947'.
} 
a few economic development and public welfare schemes, its policy of looking to the US and the Commonwealth for aid might gain popular acceptance".?

The use of technical and material assistance while enhancing national traditions in the fight against Communism aligned with the political strategy of the Burmese government after the military defeat of the Communist rebels in 1950-1951. From the late 1940s on and into the 1950s there was a growing awareness that the weak Burmese state depended on external help, even though, for domestic political reasons, Burmese leaders were very reluctant with receiving it. ${ }^{10}$ On top of this, the US (covert) support to the Kuomintang troops in the northern regions of Burma did not go down well with the political elite in Rangoon. ${ }^{11}$

The US crusade against Communism in SEA included soft policies such as cultural diplomacy and financial aid to covert operations, cooperation with authoritarian local leaders and even direct military involvement. The need of social reform was framed within a dominant anti-Communist paradigm, and this favored short-term policies typically focusing on power relations. This created a trade-off, where the fight for security in the short run threatened the long-term goal of stabilizing SEA societies. This was acknowledged even by US observers in the early 1960s, asking the question: "How effectively has the United States employed its power and influence to promote meaningful, economic, and social reform in the region?" (Henderson 1963, 260; see also Fifield 1963). The rhetoric of "development" stepped up the US strategy of accompanying social security with anti-Communism in the area. President Truman, in his inaugural message, stated that: "We must embark upon a bold new program for making the benefits of our scientific advances and industrial progress available for the improvement and growth of underdeveloped areas. [...] Democracy alone can supply the vitalizing force to stir the

\footnotetext{
${ }^{9}$ FRUS, 1950. Vol. 6, document 115, 'Policy Statement prepared in the Department of State, 16 June 1950'.

${ }^{10}$ See for example FRUS, 1951, Vol. 8, document 131, 'Memorandum by the Central Intelligence Agency, 1 August 1951'.

${ }^{11}$ In the US reports this is a frequent topic: The Burmese leadership points out to this as a fact, the US officials deny any support and the debate goes on, creating frustration especially in Rangoon.
} 
peoples of the world into triumphant action, not only against their human oppressors, but also against their ancient enemies-hunger, misery, and despair" (Truman 1949, 2).

For Britain, "development" became a key concept in its strategies for maintaining the British Empire, now in the form of the Commonwealth, and for checking the spread of Communism. The British parliament debated Burma and Malaysia on several occasions, including the Colonial Development and Welfare Act of 1950. ${ }^{12}$ There was a shared understanding that modernization and "a higher standard of life there will do more to combat Communism than militarism" ${ }^{13}$ However, there was some disagreement on the question if British support for colonies (including former territories such as Burma) should aim at economic development or social welfare (see Schmitt, Chap. 6, this volume). The proponents of the former argued that economic growth would lead to growing social stability and warned that throwing in social reforms would include an economic burden the countries could not bear. This strategy had also the advantage of serving British economic interests in these countries as well. On the other hand, the advocates of a more welfarist strategy did not deny the need for economic development but emphasized the virtues of also including social reform:

Let us strengthen our friendship with these people by developing social schemes, and at the same time ensuring a more equitable distribution of the wealth that is being won in the Colonies. A higher standard of life there will do more to combat Communism than militarism. We cannot destroy Communism by militarism any more than we can destroy a plague by power; it knows no frontiers. But we can destroy an ideology by a better and a nobler one. ${ }^{14}$

Whereas the British came to terms with Burma's independence and sensibility toward outside interference, they could pursue a more active strategy in Malaysia where several welfare reforms had been introduced

\footnotetext{
${ }^{12}$ HMSO, Colonial Development and Welfare Bill, 1950, vol. 480 cc 1135-251. http://hansard. millbanksystems.com/commons/1950/nov/09/colonial-development-and-welfare-bill.

${ }^{13}$ Ivi. § 1176.

${ }^{14}$ Ibidem.
} 
prior to independence in 1957. Britain also acted through the Commonwealth, as exemplified by the Colombo-Plan of 1950 (Oakman 2010). This Australian initiative created a lasting regional organization with the purpose of strengthening economic and social development in the Asia-Pacific region. The idea of the plans was, according to Adeleke $(2004,594)$, to "resolve the correlation between poverty and communism". It allowed the UK (and the US) to assist indirectly through a regional organization and served as an element of the regional containment of Communism (Lowe 2009).

It is important to note, however, that also for Britain military and social spending were two competing strategies in securing Asia against Communism. In his Security in the Colonies report to the British government, General Sir Gerald Templer-the most important advocate of the "hearts and minds" strategy in Malaysia_pointed out that:

Apart from the problem of raising money from the Treasury, there is the problem of seeing that Colonial territories spend their own money to the best effect. Here of course one comes up at once against the old constitutional snag; they can spend it as they please. But there is one aspect of public finance in the Colonies which is directly relevant to this Report, and that is the conflict between the claims of "welfare" and "law and order". There are two main ways of tackling Communism-economic action, to prevent or check it at the source, and police action, to contain or suppress it. In the Colonies the emphasis has hitherto been on the first approach, which is obviously the only constructive one. But if Malaya had spent on law and order a fair proportion of the large sums she was devoting to welfare, the present emergency, with the attendant colossal expenses, might well have been avoided. I submit, therefore, that the state of the cold war to-day and of our defences against it, may call for a temporary change of emphasis. Improving economic conditions do not always mean political tranquility; on the contrary, the desire to see improvement accelerated is a potent source of unrest. In the process of evolution, the development of welfare must not allow the preserving of public order-a primary function of the government-to go neglected. The Romans put communications and policing first; and it is still true that, unless these are sound, social and political development cannot be given full rein. This truth should be driven 
home, in whatever ways are most appropriate, to Colonial administrations. ${ }^{15}$

The US and Britain were not the only international players advocating social reform as a way of achieving socio-political stability. France, the other major colonial power in the region, played the Cold War card to internationalize its own conflict with the Viet Minh, at the time when the Communist Party was seizing power in China. While the British and French approaches regarding decolonization changed on a case-by-case basis, in the years 1947-1948 both identified the struggle against the national liberation movements with the international conflict with Communism. This strategy was meant to justify military commitment in the area toward the international public opinion and to ensure US support.

The contacts between the three Western powers resulted in the attempt to establish informal tripartite consultation bodies. They were meant to share information and coordinate actions in the area to secure the "freedom" of the region, by military assistance and by "favoring the economic development and standards of living of the Southern Asian countries. [The powers] will jointly carry on the implementation of measures that could ensure economic balance and social progress." ${ }^{16}$ Eventually, also for France the issue of "development", meant both in its economic (infrastructures, industry, trade) and social (assistance, social insurances, healthcare) aspects, became fundamental for containing Communism. In divided Viet Nam, both the French and the Americans promoted economic assistance in the 1950s to counter the Communist influence coming from the North. In the words of an analyst of the time, indeed, "with the achievement of independence, political stability and the beginnings of economic development in the south, there is every reason to believe that unity, when it comes, will be established on nationalist and not on Communist terms" (Hammer 1957, 235).

\footnotetext{
${ }^{15}$ TNA, Cabinet Papers, CAB/129/76, 'Security in the Colonies, Report by general Templer to Government Committee, July 1955’, p. 11.

${ }^{16}$ MAE, E/170/5, 'Défense de l'Indochine. Stratégie Commune, Janvier 1952-Juin 1952'.
} 
International organizations, regional institutions and nongovernmental organizations (NGOs) (such as the Rockefeller and Ford Foundations from the US) were equally involved in social reform in SEA. After WWII the ILO accompanied its traditional action of promoting tripartism and social collaboration, with a greater emphasis on modernization and social security. From the end of the war on, the ILO also focused more on SEA. This was due to the persistence of structural backwardness in the region: a huge mass of seasonal agricultural workers and seasonal unemployment; slow industrialization and poor levels of protection for workers (including women and children); generally low standards of living, low wages and low productivity, and demographic pressure. All these factors represented a threat as well as an opportunity to lead the integration of SEA in the world economy, as also the local modernizing elites recognized:

Not only the prosperity of Asia but abiding world prosperity is bound up with rapid economic development in Asia and an appreciable rise in "the standards of living and the purchasing power of the Asian peoples". [...] Many Asian countries have in hands, or propose to take up shortly, the preparation and execution of far-reaching programmes of economic development and social reform. Their task will be considerably facilitated and world economic development on sound lines effectively ensured if they were able to secure assistance from such international agencies as the Social and Economic Council of the United Nations, the International Bank for Reconstruction and Development and the I.L.O. (ICWA 1947, 16)

The organization of the 1947 Asiatic Regional Conference, two years after WWII, was more important in the eyes of the ILO experts, who were confident that local governments wanted to take advantage of their expertise to set up national programs for social and economic development. The Conference brought together Western and local policy-makers to discuss ways of raising the living standards of the people, by introducing guidelines for social security, healthcare, social services and employment policy reforms. At the same time the Conference highlighted the emergence of the Asian countries as independent actors on the international stage. SEA was a pivotal region in determining domestic and 
international stabilization through freedom and social justice. Indian Prime Minister Jawaharlal Nehru stressed that greater social inclusion and the progress of the newly independent or still colonial territories would grant international stability and economic growth. Recalling the 1944 Philadelphia Declaration, he stated that this would assure a new world order based on common social outlooks: "the well-being of the people living in those regions was exceedingly important. It was not a question of rich and powerful countries being generous. It was in their own interest to prevent infectious disease and poverty. Poverty anywhere was a danger to prosperity anywhere." 17

The recommendations of the Conference moved in this direction. Social security was set as the first item on the agenda. Its implementation was conditional to measures "providing for an adequate growth and supply of essential foodstuffs sufficient to meet the accepted standards of subsistence and nutrition, a living wage, decent housing and a healthy environment and free and compulsory education" (ILO 1947, 273). The general guidance on social security reform was modeled on general principles and administrative arrangements that recalled common European standards: "security for all" and "income maintenance", to be achieved through an integral and long-term plan of tripartite-funded social insurances, employment injury benefits (both industrial and agricultural), maternity benefits, old-age pensions and medical care services. The Director-General's report to the Conference, however, recommended proceeding with a gradual approach, attentive to regional differences in the social and occupational stratifications (Phelan 1947).

The Technical Assistance Programmes (TAP) started in SEA soon thereafter. They were meant to provide ILO's technical expertise in the drafting of comprehensive socio-economic reform to the governments that formally requested it. They were full-fledged state-building programs in "the Western way", which included social security, employment policies, vocational training, manpower organization and so forth. The ILO put in place a sequence of TAP in almost all the countries of the region at least until the early 1960s. Newly independent Burma was the first

\footnotetext{
${ }^{17}$ ILOA, RC/158-1, 'The Indian Information Service, Conference of Historic Significance in New Delhi, 31/10/1947', p. 1.
} 
government that joined the extended programs in 1952 and for the whole decade (ILO 1952, 1958), and the Burmese TAP became the pilot program for the others, those for Viet Nam (ILO 1956, 1959) and Malaysia (ILO 1960) probably being the most extended and long lasting of all.

The TAP did not have ideological goals in the stricter sense; individual ILO officials might have had different views on the goals of social reform, but the archival documentation does not reveal any direct political involvement in the elaboration of social security programs. According to historian Daniel Maul, however, such programs were far from providing merely neutral technical assistance. On the contrary, created by American ILO Director-General David Morse, the TAP were "motivated by the looming Cold War and the nation-building imperatives generated by decolonization in Asia" and they were designed to be "an effective means of shaping the domestic policies of the 'developing countries' in such a way-basically by raising the productivity of their economies - as to render them immune to the rise of Communism" (Maul 2016, 110-111).

The assistance programs for social enhancement contributed to the Western rhetorical arsenal of human rights and development, which was also used in the 1960s in the competition against Soviet Russia during decolonization in Africa (Maul 2012; Hilger 2017; Lorenzini 2017). In the harshest years of the Cold War, ILO stood on the side of the Western powers. The active promotion of social security in SEA since 1945 was functional to the strategy of the Western powers to counter Communist influence. It offered attractive prospects for newly independent countries to maintain democratic institutions while supporting social enhancement. And, by doing so, to stay in the Western orbit.

There was a shared concern among the major Western powers and agencies of the possible spread of Communism in SEA in the late 1940s and 1950s. As we have shown, there was also a recognition that the battle against Communism could not be won only with military means. Social reform and economic modernization thus became a key element of the strategies for state-building and keeping SEA safe against Communism. The multiple actors, of course, had slightly different views on this. For the US, it was mainly geo-strategical concerns related to the global Cold War, with some variations between State Department and other groups of experts. For the British, it was also a matter of colonial power and legacies 
within the framework of the Commonwealth. The ILO generally had a more specific and technical agenda, reflecting the narrower purpose of the organization. However, as we will see in the next section, such ideas also drew from the domestic level. Domestic actors and the interaction between the international Cold War and domestic policy-making have to be included in the shaping of early welfare state in SEA.

\section{The Local Actors and the Welfare Legislation: Hampering Communism and Building State Policies}

The state-building of newly independent political elites (Burma) or by gatekeeper colonial governments (Federation of Malaysia) required political legitimization through social inclusiveness. Local elites sought for it regardless of the great powers' international political considerations. In both countries, some policy areas enforced the "hearths and minds" asset of the struggle against Communism: public schemes to bolster the loyalty of civil servants and public sector as well as social insurances for farm and industrial workers; programs that favored socio-economic development (e.g. land reforms); health policy and medical care; and education. These actions were expected to bring political stability through economic modernization and social security.

Already since the late 1940s, the concept of "welfare state" was linked to the new Burmese state. As we have seen, British politicians and newspapers labeled the new Burmese constitution a welfare state constitution. The concept gained more political leverage as it became the key concept for the modernization strategies of the early 1950s. Several books and articles by international observers described Burma as an emerging welfare state (Trager 1958, 1959; Lockwood 1958; H.T. 1955). The first Burmese "two-year plan" (the "Sorrento Villa Plan", 1947-1948) had only limited effect because of the many Communist and ethnic insurgencies. The plan included a land reform and fostered the growth of the public sector within the field of infrastructure and public utilities; employment in the public sector rose from just above 50,000 in the 
1940 s to 250,000 in the 1950 s (Taylor 1987). The background was the intense struggle against the Communists, amplified by the influence of Communist China on the Chinese minority, to such an extent that "winning the hearts and minds of the rural poor meant winning the then ongoing battle against the communist" (Than 2013, 639). However, dayto-day war on Communist insurgents prevented long-term strategic considerations and the steady strengthening of Burmese state's structures (Taylor 1987).

In 1951-1952, with the stabilization of domestic security, the $\mathrm{Nu}$ government started more consistent social and economic development programs (Lockwood 1958, 391; Trager 1958). The government cooperated with UN agencies and, despite stern skepticism toward the US, it also invited, in 1951, the American consulting firm Knappen Tippetts Abbett McCarthy (KTA) to work out a comprehensive analysis of the challenges and potentials of economic modernization in Burma. The report was financed by the US Technical Cooperation Administration and produced a detailed (more than 800 pages) analysis that was submitted to the government in $1953 .{ }^{18}$ Based on the drafts of the report, the Nu government launched the development plan, called New Burma Program in 1954, which spelled out the so-called Pyidawtha-plan, which was presented to thousands of AFPFL delegates from all over the country in 1952. The preamble declared that "Burma can become one of the most prosperous nations of all Asia. In this New Burma we can enjoy a high standard of living, health and security for our people, social justice for all." ${ }^{19}$ The plan included ten overarching policy areas: regional development, health, education, economy, nationalization (of arable lands), transportation, welfare, democratic local councils, development of frontier areas and rebuilding. Public welfare and utilities were at the heart of the plan, even

\footnotetext{
${ }^{18}$ Economic and Engineering Development of Burma. Prepared for the Government of the Union of Burma by Knappen, Tippetts, Abbett, McCarthy in Association with Pierce Management and Robert R. Nathan Associates, Aylesbury 1953. Online version see: https://www.nathaninc.com/ insight/economic-and-engineering-development-of-burma-1953/.

${ }^{19}$ See Manual Instructions for Executions of Pyidawtha Plans (Rangoon 1952). Online version see: https://digital.soas.ac.uk/content/LO/AC/00/00/74/00001/PDF.pdf. See also PYIDAWTA. The new Burma. A report from the Government to the People of the Union of Burma on our long-term program for Economic and Social Development (1954). For an online version see: https://www. nathaninc.com/insight/economic-and-engineering-development-of-burma-1953/.
} 
though it also had an undertone of economic modernization as a precondition for welfare reform. The project covered rural health centers, new hospitals, more and better buildings for schools, high schools and vocational schools, public housing program, nurseries and child guidance clinics, training of social workers and so forth.

The comparison between the English and the Burmese version of the documents testifies to the domestic political use made of the plan. The semantic strategy made modernization safe for the Burmese, limiting the room for Communist criticism at home, while appealing to foreign capital (Than 2013, 650). Whereas the English version speaks the language of modernization theory and social engineering, the Burmese version, meant for domestic use and addressing the population, featured a much more delicate use of local references. The main challenge for $\mathrm{Nu}$ was not to give the impression of importing Anglo-American ideas of development, which would fuel accusations of dependence and imperialism by the public opinion at home. Especially as the plan included ideas of opening Burma toward foreign capital, this could be negatively interpreted as inviting new colonizers. Words such as "aid" or "foreign aid" were left out for the Burmese audience; even the title Pyidawtha, often translated as "welfare state" (Trager 1958), is, according to Than (2013, 647) "a unique Burmanization of the word development" that included references to the country's national traditions and underpinned an idea of prosperity. In this way it linked Burma's glorious history with a modernization strategy and promises of a brighter future. The link between the past and the future was also emphasized in public speeches and campaigns for the program and included references to history and Buddhism, anticipating the Buddhist revival of the early 1950s, also fostered by US observers. $^{20}$

The English-language version of the plan was more aligned with the technical language used in the KTA-report and by international experts. The Pyidawtha-plan had a threefold effect. First, it provided a strategy for Burmese modernization that allowed the country to receive aid and support from the outside: financial support from the US and the

\footnotetext{
${ }^{20}$ FRUS, 1951, Vol. 8, document 167, 'Memorandum by Acting Assistant Secretary of State for Far eastern Affairs (Allison) to Acting Secretary of State, 27 December 1951'. See also Trager $(1958,10)$.
} 
Commonwealth; technical advice from US, American foundations, the ILO; aid from both regional powers such as India and the Eastern Bloc (Lockwood 1958, 397). Second, by portraying this as a national strategy it promised an avenue of reform that confronted the Communists and could strengthen loyalty to the state. Third, the plan was consistent with the Burmese policy of non-alignment.

In line with the new party-slogan "Towards the welfare state" (Trager $1958,26)$ and the indicators set in the Pyidawtha-plan, the Burmese government in the following years presented a number of social reforms (see Lockwood 1958 for more details). The 1956 social security program was designed with the assistance of the above-mentioned TAP. It required very low contributions by industrial workers (1\% of salary), offering short-term insurance for medical and disability cases. Following ILO recommendations, it was first introduced in Rangoon and only gradually spread to the rest of the country. Still with the support of international agencies, the government undertook public health initiatives including anti-malaria programs and the establishment of the Burma Pharmaceutical Industry in 1954, securing the supply of vaccines and medication. By 1958, the Burmese Secretary to the Social Security Board assessed positively the outcomes of the governmental actions, as "the pilot scheme of social security in Burma has proved a most satisfactory beginning to the setting up of a Welfare State" (Sein 1957, 60). The report also recognized that the scheme also enjoyed positive publicity among the population and, most importantly, ensured the collaboration of workers and employers, with a few exceptions.

The strategy of the Burmese governments in the late 1940s and 1950s attired to take an autonomous path from both Western and Chinese influences, a "third way" between liberal capitalism and Communism. Most of the promises of the Pyidawtha-plan were only partially realized; Burma lacked the resources, the administrative capacity and the political stability needed. As noted by an international observer, "the road to Pyidawtha lies through a maze" (Lockwood 1958, 440). In 1956 a new, revised plan was presented, with a less ambitious and more pragmatic approach to the modernization of the country, while in 1962 the whole process was halted, as a direct result of the military coup and regime change in Burma (Maung 1964, 1187-1189; Taylor 1987, Chap. 5). 
In Malaysia, the early welfare development started under British rule. The understanding of the British was that the key to legitimacy for the UMNO and the Alliance coalition was that "a successful effort is made to relieve the very serious state of poverty and distress among the peasants" (quoted from Stockwell 1977, 511), and control of the industrial workers through trade unions which, as seen above, covered the workers of all the three main ethnicities of the country.

The reforms were a comprehensive package of social security measures that complemented the effort to boost economic growth and modernize the industrial structures of the country. Between 1950 and 1960, two plans were implemented. The above-mentioned Draft Development Plan (1950-1955) was elaborated in coordination with the British in the framework of the Colombo-Plan. It focused on social services, social security, development of infrastructures and trade. From 1956 to 1960, instead, the First Malayan Plan focused more on rural and industrial development, as well as national security (Lee and Chew-Ging 2017). During the same period, the government invited the ILO to carry out a more detailed survey on social security reform proposals. Only the subsequent Five-Years Plan, in the mid-1960s, gave new impetus for social legislation enhancement. In the industrial relations, the role of trade unions was highly regulated through the 1950 Trade Union Act, leaving their recognition to a centralized authority. Designed as a way of preventing trade unions from becoming a stronghold of Communist partisans, the act defused industrial conflict for the years to come. ${ }^{21}$ The Malaysian trade unions indeed remained relatively small, without much influence, and did not push forward expanded social rights, but on the contrary regimented industrial conflict and centralized the workers' movement (Zin et al. 2002, 128).

The core of the first wave of social reform took place in 1951-1952, simultaneously with the change of tides of guerrilla warfare against the MNLA. In 1951, a program of public pensions covered specific working categories. The Civil Service Pension was a generous non-contributory scheme for civil servants funded by the state (through taxes), also

\footnotetext{
${ }^{21}$ See also: TNA, Cabinet Papers, CAB 129/76, 'Security in the Colonies, Report by General Templer to Government Committee, July 1955', p. 64.
} 
including benefits for work injuries, disability and dependent's pensions. The Employee Provident Fund covered workers not included in the former scheme. Until 1970, the contribution was $5 \%$ of the salary, paid by both employer and employee; $60 \%$ of savings to be withdrawn at the age of 55 (as a lump sum), and the remaining can be withdrawn for housing, education or (10\% of savings) for medical expenses. In 1952 the Employer's Liability Scheme, covering employment injuries, required employers to insure their companies against accidents. This scheme did not become fully developed or significant, as it was still based on employer's liability, while many other countries had already shifted to a form of state insurance (it was replaced by the Employees Social Security Act only in 1969). Three years later, the sickness and maternity benefits (as part of the Employment Act) allocated a paid sick leave of 14-22 days, depending on length of employment. Maternity leave was 60 days (for a maximum of five children), including a benefit similar to wage.

A relevant field of social reform in Malaysia was education. As noticed by the experts of the time, "since the war the British have been pursuing a more 'enlightened' social policy than formerly. This especially notable in social welfare activities, for which a new welfare department has been founded, and primary education, which within a ten-year period is to be free to children of all races" (Thompson and Adloff 1947, 112). The British government regarded a comprehensive and compulsory basic education for all children as part of a "war of ideas" which supplemented the "war of arms". ${ }^{22}$ In 1951 these ideas turned into more detailed policy actions, marking the beginning of a decade of re-organizing the educational system which, however, did not originally move on the ethnically universalist lines advocated by the British. The colonial government's report recommended a national system with six years of primary education in Malay or English; only after protests by the Chinese community, the largest ethnic group, Chinese tracks were introduced. In 1955, a new plan for a school system with Malay as the national language was presented and enacted in 1957, after independence.

\footnotetext{
${ }^{22}$ TNA, Cabinet Papers, CAB 129/48, 'Memorandum by the secretary of state for the colonies, 21 December 1951'.
} 
In the first years since independence, the Malaysian development strategy was about economic growth leading to increasing inequality and poverty problems, particularly with regard to the living conditions in the rural areas (Zin et al. 2002, 127). The early social security system adopted some elements of universalism (the state pensions) while covering other risks in a piecemeal fashion. It aimed at winning the loyalty of specific sectors of the population through welfare policies; this was notably the case with the public sector and the growing industrial working class. At the same time social policy complied with ethnic cleavages, as demonstrated by the educational reform.

By the first half of the 1960s the Communist threat had greatly diminished; with the end of British colonial rule, the external aid for social reforms in Malaysia became primarily a matter of international organizations (see Schmitt, Chap. 1, this volume). In 1958, after full independence, the government required ILO assistance for an expanded program of social security; the expert in charge, a former civil servant of the British Ministry of Pension and National Insurance, recommended gradually strengthening the existing schemes set up in the beginning of the 1950s. The immediate amendments should enlarge the sickness and maternity benefits, by extending the provisions to the whole of the wage earners (slightly more than $50 \%$ of the active population) and, at a later stage, including specific categories of self-employed as well. It was also suggested to turn the Employer's Liability Scheme into a true state insurance and to launch pilot schemes for the improvement of medical care. The report was more cautious on unemployment benefits, due to the relative backwardness of the employment exchange service that made it impossible to collect data to plan a national unemployment scheme (ILO 1960).

The use of social reform as a key element of anti-Communist strategies also existed in the local context. Western policy-makers and technical advisors pushing for social reform as part of the state-building of stable democratic socio-political institutions heavily influenced the political elites in the two countries. This was not only a transfer of ideas fostered in Washington, London or Geneva into the domestic context. Domestic politics also played an important role for understanding of the actual timing and content of the reform agenda. In both countries it was part of party politics, and it reflected both domestic ideological considerations 
(for instance the Burmese non-alignment policy) and the existing ethnic cleavages and conflicts. In other words, Western Cold War concerns cannot alone explain specifics such as why Burma, in 1952, launched its Pyidawtha-plan or the Malaysian educational reforms of the late 1950s. We must analyze it as a complex interplay between the international Cold War and domestic politics.

\section{Conclusions}

This chapter reconsiders the relevancy of the Cold War context when explaining welfare development in the developing world (especially in the first decades after 1945). Albeit other elements such as economic development, state capacity, political actors or colonial legacies are clearly relevant factors in explaining both social policy development and outcomes, the Cold War clearly influenced (directly or indirectly) these standard explanations and provided a wider historical framework to explain the development in the area.

We argue that the timing of welfare reforms in Burma and Malaysia can be explained by looking at the larger context of the Cold War in SEA. The concerns of the Western powers about the spread of Communism in the region were even more important than those related to the decolonization process. The two cases account for similar strategies implemented by the Western powers and by non-Communist local elites, in the presence of two different juridical statuses: Burma was formally independent, while the Federation of Malaysia was still a colony of Britain. The chapter focused on the multiple levels of making use of social security and welfare policies to counter Communism. Different institutions and political actors were involved in the remolding of social policies: international organizations such as the ILO, the Western powers (the US and the UK and - with a slightly different approach-France) and the domestic nonCommunist establishments.

For the Western actors (including the ILO), social security was a plank in the process of state-building and in anchoring SEA in the Western political and economic institutions: providing economic development and social progress was deemed essential to prevent social unrest or a 
Communist seizure of power in a strategically relevant area. While the colonial powers kept acting in a colonial development manner, the US and ILO rationale already underpinned a post-colonial approach to development and modernization (Gilman 2003; Maul 2016). The ILO's less important role in outlining social reform in Malaysia than in newly independent Burma might be evidence of the competition between colonial rulers and other external actors. Social security reforms were part of the Western "hearts and minds" approach that was expected to hamper the spread of Communism in SEA. There was a broad consensus on implementing social security among Western policy-makers and policy advisors in governmental bodies as well as in international organizations.

On the other hand, the local ruling classes used social reform rhetoric and policy for their own political legitimization through economic growth, development and social inclusiveness. Social welfare reforms also resulted from the interplay between Western and local political considerations. In Burma, for the AFPFL and $\mathrm{U} \mathrm{Nu}$, social security complemented rapid industrialization, land reform, healthcare improvements and free education. The national way to Socialism combined elements of social progress and a pronounced nationalism (Aung-Thwin and Myint-U 1992). In Malaysia, the political goal was rather to lay the foundations of a more Unitarian national policy that could weaken ethnic cleavages and social discrimination. Urban and land development in the countryside, planning and social security reforms pointed at legitimizing the state in the transition from colonial rule to full independence.

As the chapter is exploratory and based on two case studies, we need to be careful when generalizing our interpretative hypotheses. However, it is not unlikely that the Cold War also served as an important frame for the social security development in other countries in SEA. Furthermore, we centered our analysis on the early Cold War, from 1945 to 1960 . However, the 1960s were also a period of intense decolonization, and our analytical frame may also apply to case studies in the 1970s and 1980s. Finally, SEA attracted very strong concerns from the major Western powers during the early Cold War. More explorations on this subject may reveal that similar concerns drove policies in the African region. We need more systematic 
and comparative research on the links between the Cold War and the welfare state in former colonial spaces.

\section{References}

Adeleke, Ademola. 2004. The Strings of Neutralism: Burma and the Colombo Plan. Pacific Affairs 76 (4): 593-610.

Aung-Thwin, Maureen, and Thant Myint-U. 1992. The Burmese Ways to Socialism. Third World Quarterly 13 (1): 67-75.

Benson, Wilfred. 1947. Preface. In Labor Problems in Southeast Asia, ed. Virginia Thompson. New Haven: Yale University Press.

Boon Kheng, Cheah. 2009. The Communist Insurgency in Malaysia, 1948-1990: Contesting the Nation-State and Social Change. New Zealand Journal of Asian Studies 11 (1): 132-152.

Bradley, Mark. 2010. Decolonization, Revolutionary Nationalism, and the Cold War, 1919-1962. In The Cambridge History of the War, ed. Melvyn P. Leffler and Odd Arne Westad, 1st ed., 464-485. Cambridge: Cambridge University Press.

Buss, Claude. 1949. International Relations in Southeast Asia. In The New World of Southeast Asia, ed. Lennox Mills, 371-433. Minneapolis: The University of Minnesota Press.

Chancellor, C.J. 1951. Nationalism in Asia: The Eleventh Conference of the Institute of Pacific Relations. International Affairs 27 (2): 184-191.

Cooper, Frederick. 1996. Decolonization and African Society. The Labor Question in French and British Africa. Cambridge: Cambridge University Press.

Dean, Vera Micheles. 1950. Impressions of Lucknow. Far Eastern Survey IXI (19): 197-201.

Eckert, Andreas. 2006. Exportschlager Wohlfahrtsstaat? Europäische Sozialstaatlichkeit und Kolobialismus in Afrika nach dem Zweiten Weltkrieg. Geschichte und Gesellschaft 32: 467-488.

Fifield, Russel H., ed. 1963. Southeast Asia in United States Policy. New York: Praeger.

Gilman, Nils. 2003. Mandarins of the Future. Baltimore: The Johns Hopkins University Press.

H.T. 1955. Awaiting the Welfare State. The World Today 11 (7): 309-318. Hammer, Ellen. 1957. Progress Report on Southern Viet Nam. Pacific Affairs 30 (3): 221-235. 
Henderson, William. 1963. Southeast Asia: Problems of United States Policy. Cambridge, MA: MIT Press.

Hilger, Andreas. 2017. Communism, Decolonization and the Third World. In The Cambridge History of Communism. Vol. 2. The Socialist Camp and World Power, 1941-1960s, ed. Norman Naimark, Silvio Pons, and Sophie QuinnJudge, 317-340. Cambridge: Cambridge University Press.

India Council of World Affairs. 1947. Asia and the I.L.O. New Delhi: Indian Council of World Affairs.

International Labour Office. 1944. Declaration Concerning the Aims and Purposes of the International Labour Organization. Adopted by the Conference at Its 26th Session. Philadelphia, 10 May 1944.

1947. Preparatory Asiatic Regional Conference of the International Labour

Organization. Appendix VII. Resolutions adopted by the Conference. New Delhi: International Labour Office.

. 1952. Expanded Programme of Technical Assistance. Report to the Government of the Union of Burma on Social Security. Geneva: International Labour Office.

- 1956. Programme ordinaire d'assistance technique. Rapport au Gouvernement du Viet-Nam sur la sécurité sociale. Genève: Bureau Internationale du Travail.

- 1958. Expanded Programme of Technical Assistance. Report to the Government of the Union of Burma on Social Security. Geneva: International Labour Office.

-1959. Programme élargi d'assistance technique. Rapport au Gouvernement du Viet-Nam sur la sécurité sociale. Genève: Bureau Internationale du Travail. - 1960. Expanded Programme of Technical Assistance. Report to the Government of the Federation of Malaya on Social Security. Geneva: International Labour Office.

Jensen, Steven. 2016. Decolonization-Not Western Liberal-Established Human Rights on the Global Agenda. September 29. https:/www.openglobalrights. org/decolonization-not-western-liberals-established-human-rights-on-g/.

Knorr, Klaus. 1950. The European Welfare State in the Atlantic System. World Politics 3 (4): 417-449.

Komer, Robert. 1972. The Malayan Emergency in Retrospect: Organization of a Successful Counterinsurgency Effort. A Report Prepared for Advanced Research Projects Agency. Santa Monica: Rand.

Lee, Cassey, and Lee Chew-Ging. 2017. The Evolution of Development Planning in Malaysia. Journal of Southeast Asian Economies 34 (3): 436-461. 
Lockwood, Agnese Nelms. 1958. The Burma Road to Pyidawtha. International Conciliation 518: 383-450.

Lorenzini, Sara. 2017. The Socialist Camp and the Challenge of Economic Modernization in the Third World. In The Cambridge History of Communism. Vol. 2. The Socialist Camp and World Power, 1941-1960s, ed. Norman Naimark, Silvio Pons, and Sophie Quinn-Judge, 341-363. Cambridge: Cambridge University Press.

Lowe, Peter. 2009. Contending with Nationalism and Communism: British Policy Towards South-East Asia, 1945-1965. New York: Palgrave Macmillan.

Mackenzie, K.E. 1952. Malaya: Economic and Commercial Conditions in the Federation of Malaya and Singapore. London: HMSO.

Maul, Daniel. 2012. Human Rights, Development and Decolonization: The International Labour Organization, 1940-70. London: Palgrave Macmillan. . 2016. The ILO, Asia and the Beginning of Technical Assistance, 1945-1960. In The ILO from Geneva to the Pacific Rim: West Meets East, ed. Nelson Lichtenstein and Jill Jense. London: Palgrave Macmillan.

Maung, Mya. 1964. Socialism and Economic Development of Burma. Asian Survey 4 (12): 1182-1190.

Mills, Lennox. 1949. Problems of Self-Government. In The New World of Southeast Asia, ed. Lennox Mills, 288-342. Minneapolis: The University of Minnesota Press.

Oakman, Daniel. 2010. Facing Asia: A History of the Colombo Plan. Canberra: ANU Press.

Obinger, Herbert, and Carina Schmitt. 2011. Guns and Butter? Regime Competition and the Welfare State during the Cold War. World Politics 63 (2): 246-270.

Petersen, Klaus. 2013. The Early Cold War and the Western Welfare State. Journal of International and Comparative Social Policy 29 (3): 226-240.

Phelan, Edward. 1947. Preparatory Asiatic Regional Conference of the International Labour Organization. Report of the Director-General. New Delhi: International Labour Office.

Rudner, Martin. 1972. The Draft Development Plan of Malaya 1950-55. Journal of Southeast Asian Studies 3 (1): 63-96.

Sacks, Milton. 1950. The Strategy of Communism in Southeast Asia. Pacific Affairs 23 (3): 227-247.

Seekings, Jeremy. 2011. British Colonial Policy, Local Politics, and the Origins of the Mauritanian Welfare State, 1936-50. Journal of African History 52 (2): 157-177. 
Sein, Maung. 1957. The Development of Social Security in Burma, 1954-57. International Labour Review 76: 47-60.

Spitzer, Alan. 1962. The Good Napoleon II. French Historical Studies 2 (3): 308-329.

Stockwell, A.J. 1977. The Formation and First Years of the United Malays National Organization (U.M.N.O.), 1946-1948. Modern Asian Studies 11 (4): 481-513.

Taylor, Robert. 1987. The State in Burma. London: C. Hurst \& Co.

Than, Tharapi. 2013. The Languages of Pydawtha and the Burmese Approach to National Development. South East Asia Research 21 (4): 639-654.

Thompson, Virginia. 1947. Labor Problems in Southeast Asia. New Haven: Yale University Press.

Thompson, Virginia, and Richard Adloff. 1947. Britain's Policy in Malaya. Far Eastern Survey 16 (10): 112.

- 1950. The Left Wing in Southeast Asia. New York: William Sloane Associates.

Trager, Frank N. 1958. Building a Welfare State in Burma, 1948-1956. New York: Institute of Pacific Relations.

- 1959. The Propaganda Battle in India and Burma. The Annals of the American Academy of Political and Social Sciences 324: 55-65.

Truman, Henry. 1949. Inaugural Address, January 20, 1949. In World Economic Progress through Cooperative Technical Assistance. The Point Four Program. The Department of State, Washington: US Government Printers Office.

Westad, Odd Arnet. 2005. The Global Cold War: Third World Interventions and the Making of Our Times. Cambridge: Cambridge University Press.

Westad, Odd Arne. 2017. The Cold War: A World History. New York: Basic Books. Zin, Ragaya Haji Mat, Hwok Aun Lee, and Saaidah Abdul-Rahman. 2002. Social Protection in Malaysia. In Social Protection in Southeast and East Asia: Towards a Comprehensive Picture, ed. Erfried Adam, Michael von Hauff, and Marei John, 119-169. Singapore: Frederich Ebert Stiftung. 
Open Access This chapter is licensed under the terms of the Creative Commons Attribution 4.0 International License (http://creativecommons.org/licenses/ by/4.0/), which permits use, sharing, adaptation, distribution and reproduction in any medium or format, as long as you give appropriate credit to the original author(s) and the source, provide a link to the Creative Commons licence and indicate if changes were made.

The images or other third party material in this chapter are included in the chapter's Creative Commons licence, unless indicated otherwise in a credit line to the material. If material is not included in the chapter's Creative Commons licence and your intended use is not permitted by statutory regulation or exceeds the permitted use, you will need to obtain permission directly from the copyright holder.

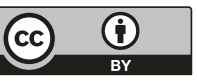

